\title{
Feline eosinophilic keratitis
}

\author{
Ceratite eosinofílica felina \\ Fabiana Quartiero Pereira', Cláudia Skilhan Faganello², Bernardo Stefano Bercht ${ }^{2}$, \\ Luciana Almeida Lacerda' \& João Antonio Tadeu Pigatto ${ }^{3}$
}

\begin{abstract}
Eosinophilic keratitis, or proliferative keratoconjunctivitis, is a chronic keratopathy that affects cats and horses. It is caused by a suspected immune mediated response to an unknown antigenic stimulus. A 5-year-old, spayed female, Domestic Short-haired cat was referred to the Ophthalmology Section of the Hospital de Clínicas Veterinárias at Federal University of Rio Grande do Sul. It had a history of ocular discomfort and ulcerative keratitis, with white plaque affecting a variable portion of the cornea and bulbar conjunctiva, in the left eye, that was nonresponsive to treatment for several months. The right eye was normal. A diagnosis of eosinophilic keratitis was made based on clinical signs and cytologic examination of corneal scrapings. The presence of eosinophils, eosinophilic granules, and mast cells on corneal scrapings is considered diagnostic for eosinophilic keratitis. The cat responded to topical corticosteroids and thirty days after treatment the plaques had completely resolved. Based on the literature available, this is the first case of eosinophilic keratitis in a cat reported in Brazil.
\end{abstract}

Keywords: eosinophilic keratitis, proliferative keratoconjunctivitis.

\section{RESUMO}

Ceratite eosinofílica, ou ceratoconjuntivite proliferativa, é uma ceratopatia crônica que acomete gatos e cavalos. É provavelmente causada por uma resposta imunológica mediada por um estimulo antigênico desconhecido. Um felino com cinco anos de idade, fêmea, castrado, sem raça definida, foi encaminhado ao Setor de Oftalmologia do Hospital de Clínicas Veterinárias da Universidade Federal do Rio Grande do Sul. Apresentava um histórico de desconforto ocular e ceratite ulcerativa com placas esbranquiçadas acometendo diversas porções da córnea e da conjuntiva bulbar do olho esquerdo. Não houve resposta ao tratamento prévio. $\mathrm{O}$ olho direito não apresentava alterações. O diagnóstico de ceratite eosinofilica foi realizado com base nos sinais clínicos e no exame citológico do raspado de córnea. A presença de eosinófilos, grânulos eosinofílicos e mastócitos no raspado de córnea é considerado critério diagnóstico para ceratite eosinofílica. Após a reepitelização da córnea, corticosteróides foram aplicados topicamente. Trinta dias após o tratamento com corticosteróides, as placas haviam desaparecido. Com base nas informações disponíveis na literatura, esse é o primeiro caso de ceratoconjuntivite eosinofílica em gato relatado no Brasil.

Descritores: gatos, ceratite eosinofílica, ceratoconjuntivite proliferativa.

${ }^{1}$ Programa de Pós-graduação em Ciências Veterinárias (PPGCV), Faculdade de Veterinária (FaVet), Universidade Federal do Rio Grande do Sul (UFRGS), Av. Bento Gonçalves 9090, Agronomia, 91540-000 Porto Alegre, Rio Grande do Sul, RS, Brasil. ${ }^{2}$ Graduação, FaVet, UFRGS. ${ }^{3}$ Departamento de Medicina Animal, FaVet, UFRGS. CORRESPONDENCE: F.Q. Pereira [fabianaquartiero@hotmail.com - Fax: +55 (51) 3308 7305] 


\section{INTRODUÇÃO}

Feline eosinophilic keratitis (FEK) or proliferative keratoconjunctivitis is a chronic keratopathy caused by a suspected immune mediated response to an unknown antigenic stimulus [14]. The lesions have a granular and inflamatory appearance characterized by white plaques or a thick mass of granulation tissues $[4,5,8]$ on the corneal surface of cats [3-9] and horses [11]. Diagnosis of FEK is based on the observation of ophthalmic exam and confirmed using cytologic examination $[10,14]$. Most cases of eosinophilic keratitis will respond to topical dexamethasone or prednisolone acetate [3]. Topical cyclosporine is an alternative treatment to the use of topical corticosteroids [14]. There have been few reports on FEK in cats in the literature. As far as we know, this is the first case of keratitis eosinophilic in a cat being reported in Brazil.

\section{CASE REPORT}

A 5-year-old, spayed female, Domestic Shorthaired cat was referred to the Ophthalmology Section of the Hospital de Clínicas Veterinárias at Federal University of Rio Grande do Sul. It had a history of ocular discomfort and ulcerative keratitis in the left eye that was nonresponsive to treatment for several months. Slit-lamp biomicroscopy evidenced white plaques, neovascularization and irregular corneal surface on the left cornea (Figure 1). The right eye was normal. Pupillary light reflex and menace responses were intact bilaterally. Schirmer Tear Test ${ }^{1}$ I values were $18 \mathrm{~mm} / \mathrm{min}$ and 25 $\mathrm{mm} / \mathrm{min}$ in right and left eyes, respectively. Intraocular pressures were estimated with an applanation tonometer ${ }^{3}$ and found to be $19 \mathrm{mmHg}$ and $14 \mathrm{mmHg}$ in right and left eyes, respectively. Both eyes were stained by using fluorescein sodium ophthalmic strips ${ }^{2}$ and the left cornea was ulcerated. Microscopic examination of corneal scrapings revealed eosinophils and neutrophils in the left eye (Figure 2) and epithelial cells in the right eye.

Topical antibiotic solution (tobramycin $0,3 \%{ }^{4}$ ) was applied six times daily during 5 days. After corneal healing, topical corticosteroid (prednisolona acetate $1 \% 5$ ) was applied three times daily. The time to total resolution of the neovascularization and corneal plaques was four weeks (Figure 3). After the treatment the patient was six months without clinical signs, when it had a relapse. The patient was again treated with topical prednisolone for 20 days and clinical signs disappeared. It has been recommended continuous use of topical cyclosporin A $1,0 \%$ once a day.

\section{DISCUSSION}

FEK is a progressive and infiltrative disease of the cornea and its manifestation is through superficial vascularization followed by the formation of white to pink plaques which tended to become yellow in other cases $[6,8,14]$. Clinically, severe conjunctivitis and chemosis are observed and in some cases the conjunctiva has a granular, cobblestone appearance [6,8]. Furthermore, corneal edema, superficial vascularization, conjunctivitis, mucoid discharge, and some blepharospasm and prolapse of the third eyelid $[6,8]$. Corneal ulcer may or may not be present. $25 \%$ of cats with eosinophilic keratitis have a corneal ulcer in the affected eye [13]. The clinical signs in the present case were consistent with reports in the literature. The corneal ulcer was superficial and healed using topical antibiotic during 5 days.

The disease seems to have no age, breed, or sex predilection and appears unilaterally $66 \%$ of the time [8]. FEK may eventually become a bilateral condition, if left untreated. The cat, in our case, was treated during various months with topical antibiotic, however, the lesion affected only one eye. It has been hypothesized that FEK may be an immune-mediated disease or a response to certain allergic stimuli [7]. Feline Herpes Virus type 1 has been detected in corneal scrapings from cats with and without FEK $[7,15,16]$.

Presumptive diagnosis of eosinophilic keratitis can often be made based on the caracteristic findings on ophthalmic examination $[1,6,10]$. However, confirmation of the diagnosis is made by collecting a small sample of cells from the affected area of the cornea to evaluate under a microscope [9]. The presence of eosinophils, eosinophilic granules, and mast cells is considered diagnostic for FEK $[6,8,9,14]$. In the present case, the diagnosis was confirmed on the basis of cytologic findings. The citological appearance was similar to that previously described. The differential diagnoses for FEK include herpetic keratitis, keratomycosis, acid fast granuloma, corneal neoplasia, and foreign body granuloma $[6,8]$.

Topical corticosteroid is the first choice for treatment due to its efficacy, and minimal side effects $[6,8,9,12]$. Megestrol acetate has been recommended in refractory cases, but it should be used cautiously, as it also causes adrenocortical suppression, polyphagia, behavioral changes, hair loss, diabetes mellitus, mammary hyperplasia, and neoplasia [8]. Topical cyclosporine 


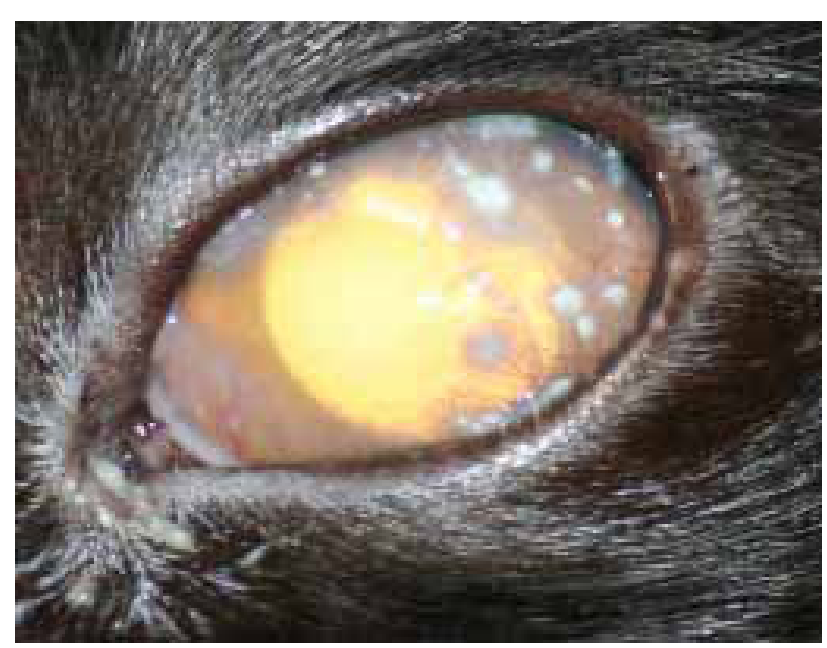

Figure 1. Gross appearance of feline eosinophilic keratitis as white plaques that partially cover portions of the left cornea. Neovascularization also is present.

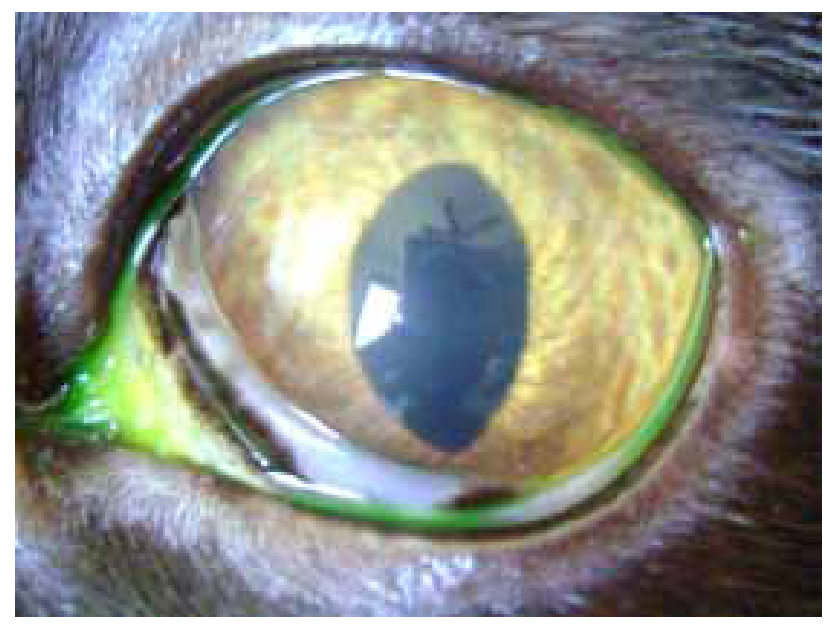

Figure 3. Left cornea after 4 weeks treatment with $1 \%$ topical prednisolone.

is an alternative treatment to the use of topical corticosteroids and did not interfere with healing of the cornea [14]. However, it can cause ocular discomfort [2]. The use of topical immunosuppressive drugs could lead to recrudescence of the possible viral infection. The topical administration of antiviral drugs may be an advantage to treat suspected cases of herpetic keratitis [2]. In chronic cases, the lesion may become intensely proliferative and

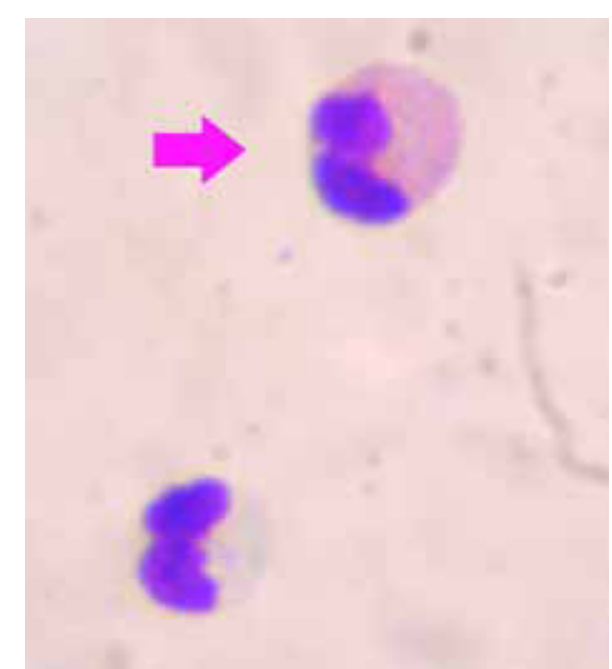

Figure 2. Corneal scraping of the left affected eye, showing an eosinophil (arrow) and a neutrophil. Panotic staining, 1000x magnification, oil immersion.

a superficial keratectomy may be required [9]. In the present case, only topical corticosteroid was used and the response was satisfactory. In the fourth week of treatment the white plaques and neovascularization had disappeared. Most cats respond well to treatment and the disease is controlled in a few weeks $[6,8,14]$. However, many cats need permanent or intermittent medication to keep the disease under control $[6,8,14]$. The recurrence rate of FEK may be greater than $64 \%$ [6]. In the case described, after the treatment the patient was six months without clinical signs, when it had a relapse. The patient was again treated with topical prednisolone $1 \%$ for 20 days and clinical signs disappeared. It has been recommended continuous use of topical cyclosporin A 1\% once a day [14].

\section{SOURCES AND MANUFACTERS}

${ }^{1}$ Schirmer strips ${ }^{\circledR}$, Ophthalmos, São Paulo, SP/Brasil. ${ }^{2}$ Fluoresceina strips ${ }^{\circledR}$, Ophthalmos, São Paulo, SP/Brasil.

${ }^{3}$ Tono-Pen Avia ${ }^{\circledR}$, Reichert, New York, USA.

${ }^{4}$ Tobrex eyedrops $0,3 \%{ }^{\circledR}$, Alcon, São Paulo, SP/Brasil.

${ }^{5}$ Pred Fort eyedrops $1 \%{ }^{\circledR}$, Allergan-Frumtost, São Paulo, SP/ Brasil.

\section{REFERÊNCIAS}

1 Allgoewer I., Schaffer E.H., Stockhaus C. \& Vogtlin A. 2001. Feline eosinophilic conjunctivitis. Veterinary Ophthalmology. 4(1): 69-74.

2 Burgesser K.M., Hotaling S., Schiebel A., Ashbaugh S.E., Roberts S.M. \& Collins J.K. 1999. Comparison of PCR, virus isolation, and indirect ?uorescent antibody staining in the detection of naturally occurring feline herpesvirus infections. Journal of Veterinary Diagnostic Investigation. 11(2): 122-126.

3 Collins B.K., Swanson J.F. \& MacWilliams P.S. 1986. Eosinophilic keratitis and keratoconjunctivitis in a cat. Modern Veterinary Practice. 67(1): 32-35. 
4 Gelatt K. N. 2003. Manual de Oftalmologia Veterinária. Barueri: Manole, 309-310, 361p.

5 Hodges A. 2005. Eosinophilic keratitis and keratoconjunctivitis in a 7-year-old domestic shorthaired cat. The Canadian Veterinary Journal. 46(11): 1034-1035.

6 Morgan R.V., Abrams K.L. \& Kern T.J. 1996. Feline eosinophilic keratitis: A retrospective study of 54 cases: (1989-1994). Veterinary \& Comparative Ophthalmology. 6(2): 131-134.

7 Nasisse M.P., Glover T.L., Moore C.P. \& Weigler B.J. 1998. Detection of Feline Herpesvirus 1 DNA in corneas of cats with eosinophilic keratitis or corneal sequestration. American Journal of Veterinary Research. 59(7): 856-858.

8 Paulsen M.E., Lavach J.D., Severin G.A. \& Eichenbaum J.D. 1987. Feline eosinophilic keratitis: A review of 15 clinical cases. Journal of the American Animal Hospital Association. 23(1): 63-69.

9 Prasse K.W. \& Winston S.M. 1996. Cytology and histopathology of feline eosinophilic keratitis. Veterinary and Comparative Ophthalmology. 6(2): 74-81.

10 Prasse K.W. \& Winston S.M. 1999. The eyes and associated structures. In: Cowell R.L., Tyler R.D. \& Meinkoth J.H. (Eds). Diagnostic Cytology and Hematology of the Dog and Cat. 2nd edn. St. Louis: Mosby, pp.75-76.

11 Ramsey D.T., Whiteley H.E., Gerding P.A \& Valdez R.A. 1994. Eosinophilic keratoconjunctivitis in a horse. Journal of the American Veterinary Medical Association. 205(9): 1308-1311.

12 Roberts S.M., Lavach J.D., Macy D.W. \& Severin G.A. 1984. Effect of ophthalmic prednisone acetate on the canine adrenal gland and hepatic function. American Journal of Veterinary Research. 45(9): 1711-1714.

13 Slatter D. 2005. Fundamentos de Oftalmologia Veterinária. 3.ed. São Paulo: Roca, 315pp

14 Spiess A.K., Sapienza J.S. \& Mayordomo A. 2009. Treatment of proliferative feline eosinophilic keratitis with topical 1.5\% cyclosporine: 35 cases. Veterinary Ophthalmology. 12(2): 132-137

15 Stiles J. \& Pogranichniy R. 2008. Detection of virulent feline herpesvirus-1 in the corneas of clinically normal cats. Journal of Feline Medicine \& Surgery. 10(2): 154-159.

16 Townsend W.M., Stiles J., Guptill-Yoran L. \& Krohne S.G. 2004. Development of a reverse transcriptasepolymerase chain reaction assay to detect feline herpesvirus-1 latency-associated transcripts in the trigeminal ganglia and corneas of cats that did not have clinical signs of ocular disease. American Journal of Veterinary Research. 65(3): 314-319. 